\title{
PENGARUH PROMOSI DAN KEPERCAYAAN NASABAH TERHADAP KEPUTUSAN PENGGUNAAN LAYANAN DIGITAL DI BANK SUMSEL BABEL CABANG PRABUMULIH
}

\author{
Laidi Subardi \\ Sekolah Tinggi Ilmu Ekonomi Rahmaniyah Sekayu \\ Email : laidyz@yahoo.com
}

\begin{abstract}
ABSTRAK
Penelitian ini bertujuan untuk mengetahui'Pengaruh Promosi dan Kepercayaan Nasabah, terhadap Keputusan Penggunaan Layanan Digital oleh Nasabah Bank SUMSEBABEL Cabang Prabumulih. Desain penelitian ini menggunakan kuesioner yang sebelumnya dilakukan uji validitas, yang diisi oleh 100 responden. Terdapat pengaruh yang positif promosi $\left(\mathrm{X}_{1}\right)$ dan kepercayaan nasabah $\left(\mathrm{X}_{2}\right)$ secara bersama-sama maupun parsial terhadap keputusan penggunaan layanan digital $(\mathrm{Y})$.

Persamaan regresi menghasilakn $Y=\mathbf{1 , 0 5 5}+\mathbf{0 , 3 7 3 X _ { 1 }}+\mathbf{0 , 3 2 0} \mathbf{X}_{2}+\mathbf{e}$. Intepretasi persamaan tersebut, nilai konstanta sebesar 1,055 menunjukkan bahwa jika Promosi $\left(\mathrm{X}_{1}\right)$, dan Kepercayaan Nasabah $\left(\mathrm{X}_{2}\right)$ dianggap tidak ada (nol) maka Keputusan Penggunaan Layanan Digital (Y) sebesar 1,055. Promosi $\left(\mathrm{X}_{1}\right)$ sebesar 0,373 berslope positif, hal ini menyatakan bahwa jika Promosi $\left(\mathrm{X}_{1}\right)$ mengalami kenaikan sebesar 1 satuan, maka Keputusan Penggunaan Layanan Digital (Y) akan mengalami peningkatan sebesar 0,373 atau dapat juga dikatakan bahwa semakin tinggi Promosi yang dilakukan oleh Bank SUMSELBABEL, maka akan mampu meningkatkan Keputusan Penggunaan Layanan Digital atas produk yang ditawarkan. Kepercayaan nasabah $\left(\mathrm{X}_{2}\right)$ sebesar 0,320 berslope positif, hal ini menyatakan bahwa jika Kepercayaan Nasabah $\left(\mathrm{X}_{2}\right)$ mengalami kenaikan sebesar 1 satuan, maka Keputusan Penggunaan Layanan Digital (Y) akan mengalami peningkatan sebesar 0,320 atau dapat juga dikatakan bahwa semakin tinggi tingkat kepercayaan nasabah atas suatu produk maka akan meningkatkan keputusan Penggunaan Layanan Digital atas produk yang ditawarkan oleh bank tersebut.

Penelitian ini menyimpulkan bahwa bahwa ada hubungan secara signifikan antara Variabel Bebas yaitu Promosi $\left(\mathrm{X}_{1}\right)$ dan Kepercayaan Nasabah $\left(\mathrm{X}_{2}\right)$, terhadap Variabel Terikat yaitu Keputusan Penggunaan Layanan Digital (Y) oleh Nasabah Bank SUMSEBABEL Cabang Prabumulih.
\end{abstract}

Kata Kunci: Promosi, Kepercayaan Nasabah dan Keputusan Penggunaan Layanan Digital.

\section{PENDAHULUAN}

1.1. Latar Belakang

Keberhasilan promosi dalam mempengaruhi perilaku konsumen dapat dipengaruhi kepercayaan. Pengertian kepercayaan dalam pemasaran jasa lebih menekankan pada sikap individu yang mengacu kepada keyakinan konsumen atas kualitas dan keterandalan jasa yang diterimanya, berdasarkan informasi yang diterimanya dari promosi. Menurut Garbarino dan Johnson (2012: p.56). Kepercayaan didefinisikan sebagai kesediaan untuk bersandar pada mitra bisnis yang dipercaya, menurut Kanuk and Schiffman (2010, p.30). kepercayaan berhubungan dengan niat perusahaan untuk mengandalkan mitra pertukaran mereka, bahwa kepercayaan sebagai suatu kebijakan, karena didasarkan sejauh mana perusahaan percaya bahwa mitra-mitranya memiliki niat dan motif-motif menguntungkan. Hal ini akan mendukung perilaku konsumen dalam pengambilan keputusan pembelian.

Perubahan perilaku konsumen yang didukung dengan kemajuan berbasis teknologi, sangat dirasakan sebagai suatu tantangan bagi perusahaan barang atau jasa dalam memasarkan produknya. Perilaku konsumen yang mengharapkan kemudahan dan kenyamanan dalam melakukan transaksi maka sebagai perusahaan penyedia layanan jasa perbankan harus tanggap dan responsive dengan permintaan konsumen. Bagi perusahaan yang tidak 
mampu mengantisipasi kebutuhan konsumen dalam era teknologi digital, maka perlahan dan tidak menutup kemungkinan seluruh konsumen akan meninggalkan perusahaan. Perilaku konsumen yang didukung dengan kemajuan berbasis teknologi, sangat dirasakan sebagai suatu tantangan bagi industri perbankan. Salah satu bank yang dimaksud adalah Bank Sumsel Babel. Bank Sumsel Babel memerlukan respon positif oleh konsumen dalam hal ini adalah nasabah terhadap layanan yang berbasis teknologi atau layanan digital perbankan, dengan kemajuan teknologi sangat penting bagi konsumen Bank Sumsel Babel untuk mengenal produk layanan digital tersebut sehingga pengetahuan konsumen mengenai layanan digital berperan dalam pengambilan keputusan penggunaan layanan digital di Bank Sumsel Babel .

Bank Sumsel Babel sebagai bank daerah yang terbesar di wilayah Sumatera Selatan sejak tahun 2000 sudah mempersiapkan infrastruktur untuk menuju bank dengan layanan terbaik di regionalnya. Bank Sumsel Babel yang terdiri dari: 1 Kantor Pusat, 28 Kantor Cabang, 51 Kantor Cabang Pembantu dan 97 Kantor Kas yang tersebar di seluruh wilayah sumbagsel, yang terdiri dari 2000 pegawai yang organik dan 500 pegawai non organik dan produk perbankan yang ada yaitu tabungan, giro dan kredit sedangkan produk layanan digitalnya antara lain: ATM, SMS Bangking, Internet Banking dan Phone Banking. Dari ke empat produk layanan digital penggunaan layanan digital SMS banking, internet banking dan Phone Banking masih dibawah $10 \%$ dari total nasabah keseluruhan sebanyak 685.690. data dapat dihat pada tabel .1
Tabel I.1:

Data Nasabah Pengguna Layanan Digital Th 2017.

\begin{tabular}{|c|c|c|c|c|c|}
\hline \multirow{3}{*}{$\begin{array}{l}\text { Nama } \\
\text { produk }\end{array}$} & \multicolumn{2}{|c|}{ Seluruh kantor } & \multicolumn{3}{|c|}{ KC Prabumulih } \\
\hline & \multirow{2}{*}{$\begin{array}{l}\text { Jumlah } \\
\text { nasabah }\end{array}$} & \multirow{2}{*}{$\begin{array}{l}\text { Pro- } \\
\text { sentase }\end{array}$} & \multirow{2}{*}{$\begin{array}{l}\text { Jumlah } \\
\text { nasabah }\end{array}$} & \multicolumn{2}{|c|}{ Prosentase } \\
\hline & & & & Cabang & Total \\
\hline $\begin{array}{l}\text { Total } \\
\text { nasabah }\end{array}$ & 685,690 & & 27,597 & & \\
\hline $\begin{array}{l}\text { SMS } \\
\text { Banking }\end{array}$ & 56,420 & 8.23 & 2,657 & 9.63 & 4.71 \\
\hline $\begin{array}{l}\text { Internet } \\
\text { Banking }\end{array}$ & 1,168 & 0.17 & 4 & 0.01 & 0.34 \\
\hline $\begin{array}{l}\text { Phone } \\
\text { Banking }\end{array}$ & 3,701 & 0.54 & 230 & 0.83 & 6.21 \\
\hline & 61,289 & 2,891 & & & \\
\hline
\end{tabular}

Sumber: Data dari Bank Sumsel

Babel Cabang Prabumulih, 2018

Produk layanan digital yang sudah diluncurkan oleh Bank Sumsel Babel untuk meningkatkan kepuasan konsumen dalam melakukan transaksi keuangan adalah: SMS banking, Internet banking, Phone Banking dan Kartu ATM/Debit. Berikut ditampilkan data pengguna layanan digital Bank Sumsel Babel pada Tabel 1. Namun demikian pada kenyataannya sampai dengan saat ini jumlah nasabah yang memanfaatkan layanan digital secara rata-rata masih dibawah 10\% untuk SMS Banking 8\%, Internet banking $0.017 \%$ dan Phone Banking 0,54\%. Berdasarkan data tersebut terlihat pengguna layanan digital masih dibawah $8,93 \%$ atau 61.289 dari total nasabah 685.690 nasabah, hal ini menjadi suatu tantangan tersendiri bagi Bank Sumsel Babel untuk meningkatkan nasabah yang menggunakan layanan digital.

Berdasarkan hal tersebut, masih banyak nasabah yang belum memanfaatkan layanan digital. Bank Sumsel Babel Cabang Prabumulih juga, penggunaan layanan digital juga masih sangat sedikit $10,47 \%$ dari jumlah nasabah 27.597 dalam kondisi seperti ini Bank Sumsel Babel wilayah Prabumulih ini juga mempunyai kendala dalam peningkatan penggunaan layanan digital.

Rendahnya pemanfaatan layanan digital tersebut disebabkan karena belum 
ada aktifitas promosi yang secara spesifik mendorong konsumen untuk bertransaksi lewat layanan digital. Bentuk promosi digital Bank Sumsel Babel Cabang Prabumulih yang selama ini dilakukan adalah:

1. Hadiah langsung hanya di berikan pada saat nasabah melakukan pembukaan rekening tabungan dengan jumlah nominal setoran awal diatas 5 juta.

2. Selanjutnya pemasaran langsung, hanya di lakukan secara langsung melalui custumer service.

3. Iklan yang dilakukan hanya satu arah dengan melakukan promosi melalui pamplet, spanduk, siaran radio, belum ada jadwal khusus untuk melakukan kegiatan edukasi mengenai produk layanan digital itu sendiri sehingga informasi produk yang kurang detail dan kurang informatif diterima oleh nasabah pengguna atau pun yang belum menggunakan layanan digital.

Berdasarkan fenomena tersebut maka judul penelitian ini "Pengaruh Promosi dan Kepercayaan Nasabah Terhadap Keputusan Penggunaan Layanan Digital di Bank Sumsel Babel Cabang Prabumulih".

\subsection{Perumusan Masalah}

Berdasarkan deskripsi latar belakang, maka rumusan masalah " Bagaimanakah Pengaruh Promosi dan Kepercayaan Nasabah Terhadap Keputusan Penggunaan Layanan Digital di Bank Sumsel Babel Cabang Prabumulih".

\subsection{Ruang Lingkup Penelitian.}

Penelitian ini membatasi hanya pada promosi dan kepercayaan nasabah serta keputusan menggunakan layanan digital yang diberikan Bank SUMSELBABEL Cabang Prabumulih.

\subsection{Tujuan Penelitian.}

Berdasarkan rumusan masalah, maka tujuan penelitian ini " Untuk mengetahui, Pengaruh Promosi dan
Kepercayaan Nasabah Terhadap Keputusan Penggunaan Layanan Digital di Bank Sumsel Babel Cabang Prabumulih".

\section{METODE PENELITIAN}

2.1 Lokasi Penelitian.

Penelitian ini dilakukan di Bank Sumsel Babel Cabang Prabumulih.

\subsection{Waktu dan Tempat Penelitian.}

Penelitian ini dilakukan di tahun 2018. Tempat penelitian di wilayah operasional Bank Sumsel Babel Cabang Prabumulih.

\subsection{Jenis dan Sumber Data.}

Jenis data dalam penelitian ini adalah data primer. Sumber data primer diperoleh dari isian kuisoner yang diberikan oleh respoden Nasabah Bank Sumsel Babel Cabang Prabumulih.

\subsection{Metode Pengumpulan Data.}

Penelitian ini, metode pengumpulan data yang digunakan adalah metode wawancara. Peneliti membuat kusioner sesuai dengan variabel yang diteliti, yaitu promosi, kepercayaan nasabah dan keputusan penggunaan layanan digital Bank Sumselbabel Prabumulih.

\subsection{Teknik Pengumpulan Data.}

Menurut Sugiyono (2010:402), teknik pengumpulan data adalah adalah teknik yang dapat digunakan untuk mendapatkan data atau informasi yang berkaitan dengan survei. Teknik pengumpulan data dalam penelitian ini adalah dengan mengunakan kuesioner, yaitu responden diminta untuk menjawab salah satu jawaban yang sesuai menurut pendapatnya, dengan alternatif pilihan jawaban, yaitu sebagai berikut: dengan menggunakan skala likert $1-5$ yang tergolong dalam skala interval
1) Jawaban Sangat Setuju (SS) dengan skor 5;
2) Jawaban Setuju (S) dengan skor 4; 
3) Jawaban Netral (N) dengan skor 3;

4) Jawaban Tidak Setuju (TS) dengan skor 2 ;

5) Jawaban Sangat Tidak Setuju (STS) dengan skor 1.

\subsection{Teknis Analisis Data.}

Setelah data-data terkumpul selanjutnya dianalisis. Tahap ini merupakan tahap yang paling penting dan sangat menentukan. Pada tahap analisis data diolah dan diproses menjadi kelompok-kelompok, diklasifikasikan, dikategorikan dan dimanfaatkan untuk memperoleh kebenaran sebagai jawaban dari masalah-masalah dalam hipotesis yang diajukan dalam penelitian

Untuk mengolah data yang diperoleh, penulis menggunakan dua metode sekaligus yaitu :

1). Analisis kuantitatif, yakni interpretasi dan pengukuran atas data-data hasil penelitian yang berwujud angka-angka

2). Analisis kualitatif, yakni pembahasan dan penyimpulan data-data hasil penelitian yang dinyatakan dengan tulisan, kata-kata atau kalimat.

Penelitian yang dilakukan ini bermaksud untuk mengungkapkan adanya hubungan atau pengaruh antara variabel bebas (independent variable) dengan variabel terikat (dependent variable). Dalam statistika, metode analisis yang sesuai dengan permasalahan tersebut adalah analisis regresi, dimana satu variabel terikat dipengaruhi oleh beberapa variabel bebas. Variabel terikat adalah variabel yang diasumsikan hanya muncul karena pengaruh variabel bebas tersebut.

Pada bagian sebelumnya telah ditentukan bahwa variabel terikat pada penelitian ini adalah keputusan penggunaan layanan digital Bank Sumselbabel (Y) sedangkan variabel bebasnya adalah promosi $\left(\mathrm{X}_{1}\right)$ dan kepercayaan nasabah $\left(\mathrm{X}_{2}\right)$.

Secara sistematis, hubungan fungsional variabel terikat (Y) dan variabel-variabel bebas $\left(\mathrm{X}_{1}\right.$ dan $\left.\mathrm{X}_{2}\right)$ dapat dinyatakan sebagai berikut :

$$
\mathrm{Y}=\mathrm{a}+\mathrm{b}_{1} \mathrm{X}_{1}+\mathrm{b}_{2} \mathrm{X}_{2}+\mathrm{e}
$$

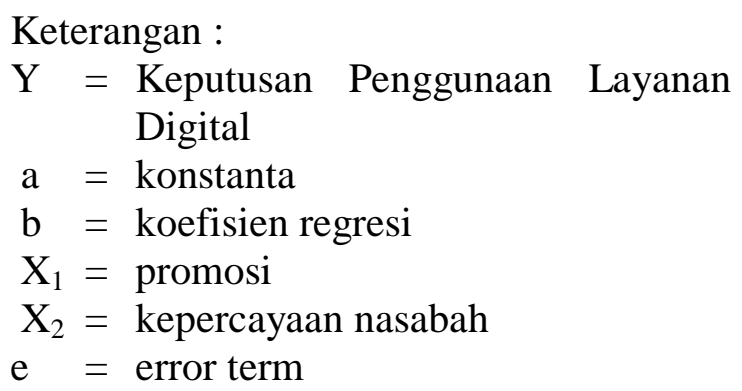

\section{PEMBAHASAN}

\section{A. Analisis Data dan Pembahasan}

1. Uji Validitas

Uji validitas akan menguji masingmasing variabel yang digunakan dalam penelitian ini. Adapun kriteria yang digunakan dalam menentukan valid tidaknya pernyataan yang digunakan dalam penelitian ini adalah sebagai berikut: tingkat signifikasi sebesar 0,05 , derajat kebebasan $(\mathrm{df})=\mathrm{n}-2=$ $100-2=98$, didapat $r$ tabel $=0,1966$. Jika $r$ hitung (untuk tiap butir dapat dilihat pada kolom Pearson Correlation pada output SPSS) lebih besar dari $r$ tabel dan nilai $r$ positif, maka butir pernyataan dikatakan valid).

a. Variabel Keputusan Penggunaan layanan digital (Y)

Tabel III.1.

Uji Validitas Variabel Keputusan Penggunaan layanan digital (Y)

\begin{tabular}{|l|l|l|l|}
\hline Item & $\begin{array}{l}\text { Corrected } \\
\text { Item-Total } \\
\text { Correlation }\end{array}$ & $\begin{array}{l}\text { r-tabel } \\
(\mathrm{N}=100)\end{array}$ & Keterangan \\
\hline $\mathrm{Y}_{1.1}$ & 0.400 & 0,1966 & Valid \\
\hline $\mathrm{Y}_{1.2}$ & 0.511 & 0,1966 & Valid \\
\hline $\mathrm{Y}_{1.3}$ & 0.363 & 0,1966 & Valid \\
\hline $\mathrm{Y}_{1.4}$ & 0.533 & 0,1966 & Valid \\
\hline $\mathrm{Y}_{1.5}$ & 0.514 & 0,1966 & Valid \\
\hline $\mathrm{Y}_{1.6}$ & 0.402 & 0,1966 & Valid \\
\hline $\mathrm{Y}_{1.7}$ & 0.454 & 0,1966 & Valid \\
\hline $\mathrm{Y}_{1.8}$ & 0.486 & 0,1966 & Valid \\
\hline
\end{tabular}

Sumber : Hasil olah data primer

Dari tabel III.1 di atas didapat hasil uji validitas akan variable Keputusan Pembelian (Y) dimana tidak terdapat itemitem yang memiliki nilai corrected ItemTotal Correlation < 0,1966 (nilai $\mathrm{r}$ tabel dengan $\mathrm{N}=100$ ), sehingga semua item 
dalam variable Keputusan Penggunaan layanan digital (Y) ini dapat dipergunakan, sehingga pernyataan untuk variable Keputusan Penggunaan layanan digital (Y) terdiri dari 8 item, yang terdiri dari : $\mathrm{Y}_{1.1}$, $\mathrm{Y}_{1.2}, \mathrm{Y}_{1.3}, \mathrm{Y}_{1.4}, \mathrm{Y}_{1.5}, \mathrm{Y}_{1.6}, \mathrm{Y}_{1.7}, \mathrm{Y}_{1.8}$.

\section{b. Variabel Promosi $\left(\mathrm{X}_{1}\right)$. Tabel III.2 \\ Uji Validitas Variabel Promosi $\left(\mathbf{X}_{1}\right)$}

\begin{tabular}{|l|l|l|l|}
\hline Item & $\begin{array}{l}\text { Corrected } \\
\text { Item-Total } \\
\text { Correlation }\end{array}$ & $\begin{array}{l}\mathrm{r} \text {-tabel } \\
(\mathrm{N}=100)\end{array}$ & Keterangan \\
\hline $\mathrm{X}_{1.1}$ & 0,425 & 0,1966 & Valid \\
\hline $\mathrm{X}_{1.2}$ & 0,442 & 0,1966 & Valid \\
\hline $\mathrm{X}_{1.3}$ & 0,427 & 0,1966 & Valid \\
\hline $\mathrm{X}_{1.4}$ & 0,411 & 0,1966 & Valid \\
\hline $\mathrm{X}_{1.5}$ & 0,455 & 0,1966 & Valid \\
\hline $\mathrm{X}_{1.6}$ & 0,499 & 0,1966 & Valid \\
\hline $\mathrm{X}_{1.7}$ & 0,513 & 0,1966 & Valid \\
\hline $\mathrm{X}_{1.8}$ & 0,394 & 0,1966 & Valid \\
\hline $\mathrm{X}_{1.9}$ & 0,443 & 0,1966 & Valid \\
\hline
\end{tabular}

Sumber: Pengolahan data primer, 2018

Dari hasil pengujian validitas terhadap item-item pada variable Promosi $\left(\mathrm{X}_{1}\right)$ seperti terlihat pada Tabel diatas, didapat hasil uji nilai hitung corrected Item-Total Correlation > 0,1966 sehingga seluruh item dinyatakan valid, sehingga pernyataan untuk Variabel Promosi $\left(\mathrm{X}_{1}\right)$ terdiri dari 9 item, yaitu : $\mathrm{X}_{1.1}, \mathrm{X}_{1.3}, \mathrm{X}_{1.3}$, $\mathrm{X}_{1.4}, \mathrm{X}_{1.5}, \mathrm{X}_{1.6}, \mathrm{X}_{1.7}, \mathrm{X}_{1.8}, \mathrm{X}_{1.9}$.

\section{c. Variabel Kepercayaan Nasabah $\left(\mathbf{X}_{2}\right)$}

Tabel III.3.

Uji Validitas Variabel Kepercayaan Nasabah $\left(\mathbf{X}_{2}\right)$

\begin{tabular}{|l|l|l|l|}
\hline Item & $\begin{array}{l}\text { Corrected Item- } \\
\text { Total Correlation }\end{array}$ & $\begin{array}{l}\text { r-tabel } \\
(\mathrm{N}=100)\end{array}$ & Keterangan \\
\hline $\mathrm{X}_{2.1}$ & 0,509 & 0,1966 & Valid \\
\hline $\mathrm{X}_{2.2}$ & 0,596 & 0,1966 & Valid \\
\hline $\mathrm{X}_{2.3}$ & 0,412 & 0,1966 & Valid \\
\hline $\mathrm{X}_{2.4}$ & 0,401 & 0,1966 & Valid \\
\hline $\mathrm{X}_{2.5}$ & 0,525 & 0,1966 & Valid \\
\hline $\mathrm{X}_{2.6}$ & 0,514 & 0,1966 & Valid \\
\hline $\mathrm{X}_{2.7}$ & 0,547 & 0,1966 & Valid \\
\hline $\mathrm{X}_{2.8}$ & 0,436 & 0,1966 & Valid \\
\hline $\mathrm{X}_{2.9}$ & 0,459 & 0,1966 & Valid \\
\hline
\end{tabular}

Sumber: Pengolahan data primer, 2018
Dari hasil pengujian validitas terhadap item-item pada variable Kepercayaan Nasabah $\left(\mathrm{X}_{2}\right)$ seperti terlihat pada Tabel diatas, didapat hasil uji nilai hitung corrected ItemTotal Correlation > 0,1966 sehingga seluruh item dinyatakan valid, sehingga pernyataan untuk Variabel Kepercayaan Konsumen $\left(\mathrm{X}_{2}\right)$ terdiri dari 9 item, yaitu : $X_{2.1}, X_{2.2}, X_{2.3}$, $\mathrm{X}_{2.4}, \mathrm{X}_{2.5}, \mathrm{X}_{2.7}, \mathrm{X}_{2.8}, \mathrm{X}_{2.9}$.

\section{Uji Reliabilitas}

Uji reliabilitas digunakan untuk mengukur konsistensi konstruk atau variabel penelitian. Mengukur uji reliabilitas dilakukan dengan menggunakan uji statistik Cronbach Alpha. Suatu konstruk atau variabel dikatakan reliabel sedang jika memberikan nilai koefisien Cronbach's Alpha lebih besar daripada 0,60. Hasil uji reliabilitas dalam penelitian ini hasilnya reliabilitas pada variabel promosi $\left(\mathrm{X}_{1}\right)$, kepercayaan nasabah $\left(\mathrm{X}_{2}\right)$ dan keputusan penggunaan layanan digital (Y), menunjukkan bahwa nilai koefisien Cronbach's Alpha dari variable bebas yang diteliti menunjukkan hasil yang beragam dan variabel menghasilkan nilai Cronbach's Alpha lebih besar dari 0,60 . Sedangkan untuk variable terikat berada pada rentang kreteria reliabilitas Cukup Reliabel. Dengan demikian dapat disimpulkan bahwa alat ukur yang digunakan dalam penelitian ini adalah reliabel.

\section{Uji Pelanggaran Asumsi Klasik}

\section{a. Uji Multikolinearitas}

Pendeteksian

terhadap multikolinearitas dapat dilakukan dengan melihat nilai VIF dari hasil analisis regresi. Jika nilai VIF > 10, terdapat multikolinearitas yang tinggi. 
Tabel III.4. Hasil Uji Multikolinearitas

Coeticients $^{\mathrm{a}}$

\begin{tabular}{|c|c|c|c|c|c|c|c|c|}
\hline \multirow[b]{2}{*}{ Undel } & & \multicolumn{2}{|c|}{ Unstantrouter Coeficients } & \multirow{2}{*}{\begin{tabular}{|c|}
$\begin{array}{c}\text { Standaruted } \\
\text { Doaficiarts }\end{array}$ \\
Beta \\
\end{tabular}} & \multirow[b]{2}{*}{$t$} & \multirow[b]{2}{*}{$\mathrm{Si}$} & \multicolumn{2}{|c|}{ Colineaty Statsics. } \\
\hline & & B & Sti Emor & & & & Taleranca & $1 / f$ \\
\hline \multirow[t]{3}{*}{1} & Constant? & 1.055 & .410 & & 2573 & 012 & & \\
\hline & Promosi & 373 & .097 & 339 & 3665 & 1000 & 953 & 1.286 \\
\hline & Yas)acapan Yonsuman & 325 & 031 & 349 & 3.42 & 100 & 933 & 1.126 \\
\hline
\end{tabular}

a Dependent Variabla:Kaptusan Penbelien

\section{Sumber : Hasil olah data primer}

Berdasarkan tabel di atas, dapat diketahui bahwa nilai VIF pada kolom terakhir pada masing-masing variabel adalah $\mathrm{X}_{1}=1,038, \mathrm{X}_{2}=1,038$ dimana semuanya lebih kecil dari pada 10 . Dengan demikian model regresi linier berganda bebas dari multikolinearitas.

\section{b. Uji Heteroskedastisitas}

Uji heteroskedastisitas diuji dengan dengan Scatterplot SPSS. Apabila sebaran titik pada scatterplot menggabarkan sebaran titik yang menyebar secara maksimal dan tidak membentuk pola sebaran tertentu maka dalam model regresi tidak terjadi heteroskedastisitas.

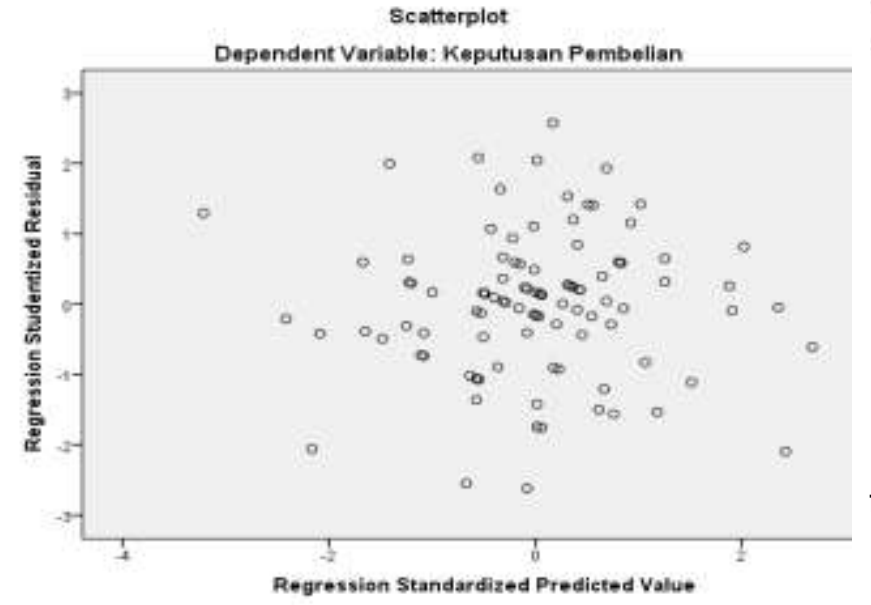

GambarIII.1. Hasil Scatterplot Uji Heteroskedastisitas.

Dari gambar III.1 Scatterplot diatas, dapat diketahui bahwa variabel bebas memiliki sebaran yang maksimal dan tidak membentuk pola tertentu atau titik tersebut berkumpul disalah satu posisi saja. Hal ini artinya variabel bebas dapat dikatakan bahwa bebas dari pelanggaran asumsi heteroskedastisitas.

\section{c. Uji AutoKorelasi}

Metode uji autokorelasi yang digunakan dalam penelitian ini adalah adalah dengan Uji Durbin-Watson (Uji DW). Hasil perhitungan Durbin Watson $(d)$ dibandingkan dengan nilai $d_{\text {tabel }}$ pada $\alpha=0,05$. Tabel $d$ memiliki dua nilai, yaitu nilai batas atas $\left(d_{\mathrm{U}}\right)$ dan nilai batas bawah $\left(d_{\mathrm{L}}\right)$ untuk berbagai nilai $\mathrm{n}$ dan $\mathrm{k}$.

- Jika $\mathrm{d}<\mathrm{d}_{\mathrm{L}}$; terjadi autokorelasi positif

- $\mathrm{d}>4-\mathrm{d}_{\mathrm{L}}$; terjadi autokorelasi negatif

- $\mathrm{d}_{\mathrm{U}}<\mathrm{d}<4-\mathrm{d}_{\mathrm{U}}$; tidak terjadi autokorelasi

- $\mathrm{d}_{\mathrm{L}} \leq \mathrm{d} \leq \mathrm{d}_{\mathrm{U}}$ atau $4-\mathrm{d}_{\mathrm{U}} \leq \mathrm{d} \leq 4-$ $\mathrm{d}_{\mathrm{L}}$; pengujian tidak meyakinkan.

Tabel III.5.

Hasil Uji Autokorelasi

Model Summary

\begin{tabular}{|l|r|r|r|r|r|}
\hline Nodel & $R$ & $R$ Square & \multicolumn{1}{c|}{$\begin{array}{c}\text { Adjusted } R \\
\text { Square }\end{array}$} & $\begin{array}{r}\text { Std. Error of } \\
\text { the Estimate }\end{array}$ & $\begin{array}{l}\text { Durbin- } \\
\text { Watson }\end{array}$ \\
\hline 1 & $531^{2}$ & 282 & 268 & .40097 & 1.742 \\
\hline
\end{tabular}

a. Predictors: (Constant), Kepercayaan Konsumen, Promosi

b. Dependent Variable: Keputusan Pembelian

Sumber : Hasil olah data primer

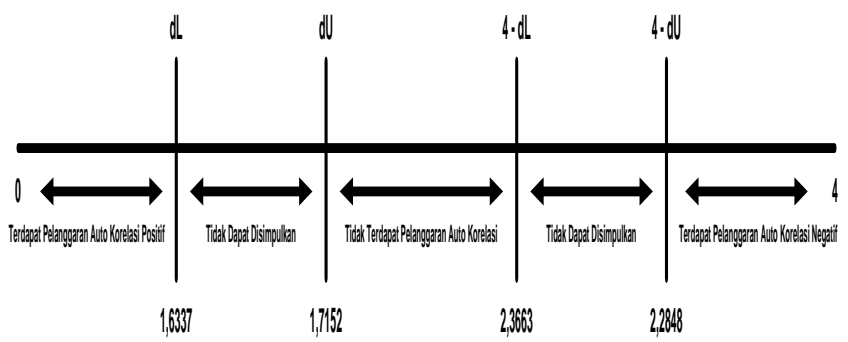

Gambar III.2.

Gambar Estimasi Uji Autokorelasi

Berdasarkan tabel III.5 serta berpedoman pada gambar 4.2 diatas didapat nilai DW dan gambar estimasi uji autokorelasi, maka dihasilkan dari model regresi adalah 1,742. Sedangkan dari tabel DW dengan signifikan 0,05 
dan jumlah data $(n)=100$, serta $\mathrm{k}=2$ (k adalah jumlah variabel bebas) diperoleh nilai $\mathrm{dL}$ sebesar 1.6337 dan dU sebesar 1.7152. karena nilai DW hitung (1,742), maka nilai DW hitung berada diantara $\mathrm{dU}>1,742>4$-dL maka dapat disimpulkan bahwa model regresi tidak terdapat pelanggaran asumsi klasik Auto Korelasi.

\section{d. Uji Linearitas}

Pengujian Linearitas pada SPSS dengan menggunakan menggunakan pola Scatterplot. Model dikatakan linier jika pola Scatterplot antara nilai residual terstandarisasi dengan nilai prediksi terstandarisasi tidak membentuk pola tertentu (acak).

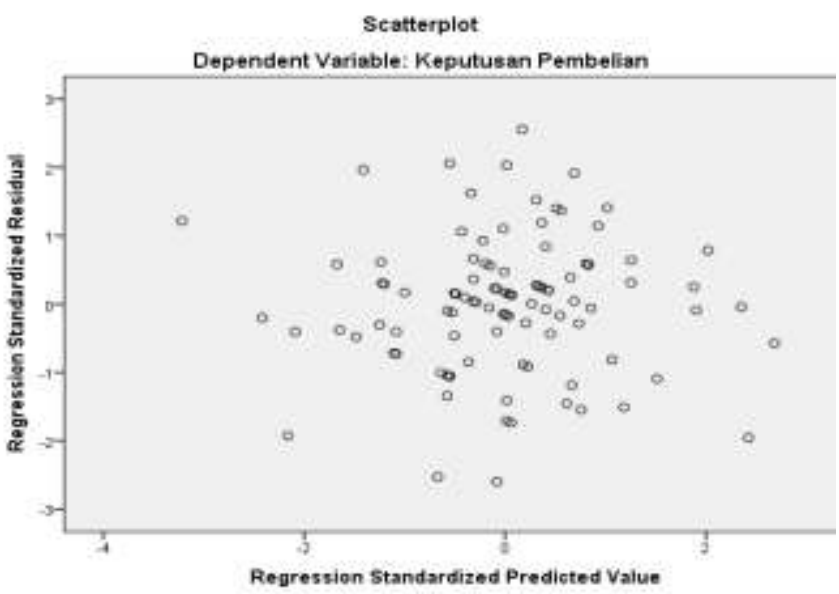

Sumber : Hasil olah data primer

Gambar 4.3. Hasil Scatterplot Uji Linearitas

Dari gambar diatas dapat diketahui bahwa sebaran titik tidak membentuk pola tertentu dan cenderung berada pada posisi acak, hal ini berarti Variabel Promosi $\left(\mathrm{X}_{1}\right)$, Kepercayaan Konsumen $\left(\mathrm{X}_{2}\right)$ memiliki hubungan yang Linear terhadap Keputusan Pembelian (Y).

\section{e. Uji Normalitas}

Uji normalitas bertujuan untuk menguji apakah dalam model regresi, variabel dependen dan independen keduanya mempunyai distribusi normal atau tidak. Uji normalitas menggunakan uji KolmogorovSmirnov, dengan uji ini dapat diketahui data yang digunakan berdistribusi normal atau tidak. Apabila nilai Asymp. Sig. (2-tailed) > 0.05, maka data tersebut berdistribusi normal dan begitu juga sebaliknya. Hasil estimasi uji normalitas tergambar pada tabel berikut ini:

Tabel III.6. Hasil Uji Normalitas

One-Sample Kolmogorov-Smirnov Test

\begin{tabular}{|c|c|c|}
\hline & & $\begin{array}{l}\text { Standardized } \\
\text { Residual }\end{array}$ \\
\hline N & & 100 \\
\hline \multirow[t]{2}{*}{ Normal Parameters ${ }^{a, b}$} & Mean & .0000000 \\
\hline & Std. Deviation & .98984745 \\
\hline \multirow[t]{3}{*}{ Most Extreme Differences } & Absolute & .080 \\
\hline & Positive & .076 \\
\hline & Negative & -.080 \\
\hline Test Statistic & & 080 \\
\hline Asymp. Sig. (2-tailed) & & $119^{\circ}$ \\
\hline
\end{tabular}

Sumber : Hasil olah data primer

Jika melihat hasil estimasi uji Kolmogorov-Smirnov diatas, dimana nilai Asymp. Sig. (2-tailed) sebesar 0,119 dan nilai tersebut berada diatas nilai P-Value $(\alpha)$ yaitu sebesar 0,05 , maka dapat disimpulkan bahwa data pada penelitian ini distribusi datanya terdistribusi dengan normal.

\section{Uji Regresi}

Analisis regresi linier berganda digunakan dalam penelitian ini dengan tujuan untuk membuktikan hipotesis mengenai pengaruh Variabel Promosi $\left(\mathrm{X}_{1}\right)$, Kepercayaan Nasabah $\left(\mathrm{X}_{2}\right)$, terhadap Variabel Terikat yaitu Keputusan Penggunaan layanan digital (Y). Perhitungan statistik dalam analisis regresi linier berganda yang digunakan dalam penelitian ini adalah dengan menggunakan bantuan program komputer IBM SPSS Statistics For Windows Relase 23.00. Hasil pengolahan datanya: 
Tabel III.7.

Hasil Koefisien Regresi Berganda

\begin{tabular}{|c|c|c|c|c|c|}
\hline & & efficie & $\mathbf{t s}^{\mathbf{a}}$ & & \\
\hline \multirow[b]{2}{*}{ Model } & \multicolumn{2}{|c|}{$\begin{array}{l}\text { Understandardized } \\
\text { Coeffcients }\end{array}$} & \multirow{2}{*}{$\begin{array}{l}\text { Standardized } \\
\text { Coeffcients } \\
\text { Beta }\end{array}$} & \multirow[b]{2}{*}{$\mathrm{t}$} & \multirow[b]{2}{*}{ Sig } \\
\hline & B & $\begin{array}{l}\text { Std. } \\
\text { Error }\end{array}$ & & & \\
\hline 1. (constant) & 1.005 & .410 & & 2.573 & .012 \\
\hline Promosi & .373 & ,096 & .339 & 3.869 & .000 \\
\hline $\begin{array}{l}\text { Keperca- } \\
\text { yaan } \\
\text { Nasabah }\end{array}$ & .320 & .080 & .349 & 3.982 & .000 \\
\hline
\end{tabular}

a. Dependent Variable: Keputusan Penggunaan Layanan Digital

Sumber: Hasil olahan data primer

Berdasarkan tabel III.7 diatas maka didapat persamaan regresi sederhana sebagai berikut:

$Y=1,055+0,373 X_{1}+0,320 X_{2}$

Intepretasi dari persamaan regresi berganda mengenai pengaruh Variabel Promosi $\left(\mathrm{X}_{1}\right)$, Kepercayaan Nasabah $\left(\mathrm{X}_{2}\right)$, terhadap Variabel Terikat yaitu Keputusan Penggunaan Layanan Digital (Y) dapat dijelaskan sebagai berikut:

- Nilai konstanta sebesar 1,055 menunjukkan bahwa jika Variabel Promosi $\quad\left(\mathrm{X}_{1}\right), \quad$ Kepercayaan Nasabah $\left(\mathrm{X}_{2}\right)$ dianggap tidak ada (nol) maka Variabel Keputusan Penggunaan Layanan Digital (Y) sebesar 1,055 .

- Koefisien regresi Variabel Promosi $\left(\mathrm{X}_{1}\right)$ sebesar 0,373 berslope positif, hal ini menyatakan bahwa jika Promosi $\left(\mathrm{X}_{1}\right)$ mengalami kenaikan sebesar 1 satuan, maka Keputusan Penggunaan Layanan Digital (Y) akan mengalami peningkatan sebesar 0,373 atau dapat juga dikatakan bahwa semakin tinggi Promosi yang dilakukan oleh perusahaan maka akan mampu meningkatkan Keputusan Penggunaan Layanan Digital atas produk yang ditawarkan.
- Koefisien regresi Variabel Kepercayaan Nasabah $\left(\mathrm{X}_{2}\right)$ sebesar 0,320 berslope positif, hal ini menyatakan bahwa jika Kepercayaan Nasabah $\left(\mathrm{X}_{2}\right)$ mengalami kenaikan sebesar 1 satuan, maka Keputusan Penggunaan Layanan Digital (Y) akan mengalami peningkatan sebesar 0,320 atau dapat juga dikatakan bahwa semakin tinggi tingkat kepercayaan nasabah atas suatu produk maka akan mampu meningkatkan keputusan penggunaan layanan digital atas produk yang ditawarkan oleh Bank Sumselbabel Cabang Palembang tersebut.

- Kedua koefisien variabel bebas berslope positif, hal ini menunjukkan hubungan linier positif (searah) antara Promosi $\left(\mathrm{X}_{1}\right)$, Kepercayaan Nasabah $\left(\mathrm{X}_{2}\right)$, terhadap Variabel Terikat yaitu Keputusan Penggunaan Layanan Digital (Y) artinya Promosi, Kepercayaan nasabah yang semakin meningkat, maka akan mampu meningkatkan Keputusan Penggunaan Layanan Digital oleh Nasabah Bank Sumselbabel Cabang Prabumulih.

\section{Uji Korelasi dan Koefisien} Determinasi

a. Uji Korelasi (R)

Analisis korelasi adalah salah satu teknik statistik yang digunakan untuk mencari hubungan antara dua variabel atau lebih yang sifatnya kuantitatif. Fungsi utama dari analisis korelasi adalah untuk menentukan seberapa erat hubungan antara satu variabel dengan variabel lainnya. Analisis Korelasi bertujuan untuk mengukur kekuatan hubungan antara dua variabel, analisis korelasi tidak membedakan antara variabel dependen dengan independen. Dari hasil estimasi data rekap jawaban responden, maka hasil koefisien 
korelasi dapat dijelaskan melalui tabel berikut ini :

Tabel III.8. Hasil Uji Korelasi.

Model Summary

\begin{tabular}{|l|l|l|l|l|}
\hline Model & $\mathrm{R}$ & $\begin{array}{l}\mathrm{R} \\
\text { Square }\end{array}$ & $\begin{array}{l}\text { Adjusted } \\
\mathrm{R} \\
\text { Square }\end{array}$ & $\begin{array}{l}\text { Std.error } \\
\text { of the } \\
\text { Estimate }\end{array}$ \\
\hline 1 & $.531^{\mathrm{a}}$ & .282 & .268 & .40097 \\
\hline
\end{tabular}

a. Predictors : (constant), Kepercayaan Nasabah.

Sumber : Hasil olah data primer

Berdasarkan hasil perhitungan, diperoleh nilai koefisien korelasi (R) sebesar 0,531, didapat dengan mengkaitkan hasil koefisien korelasi dengan tingkat keeratan antara variabel sebesar 0,531 yang berada pada interpretasi nilai korelasi $(0,40-0,599)$ artinya bahwa hubungan kedua variabel signifikan dan tingkat keeratannya Sedang (Sogiyono, 2015).

\section{b. Uji Koefiien Korelasi $\left(\mathbf{R}^{\mathbf{2}}\right)$}

Koefisien Determinasi digunakan dalam kaitannya dengan penggunaan analisis kolerasi untuk melihat besar kecilnya besaran kontribusi atas variabel bebas menjelaskan variabel terikat. Koefisien determinasi disebut juga koefisien penentu, karena varian yang terjadi pada variabel dependen dapat dijelaskan melalui variabel independen.

Dari hasil estimasi dengan penggunaan program IBM SPSS Statistics For Windows Relase 23.00 diperoleh bahwa nilai $\mathrm{R}^{2}=0,282$ yang berarti bahwa Variabel Promosi $\left(\mathrm{X}_{1}\right)$, Kepercayaan Konsumen $\left(\mathrm{X}_{2}\right)$ mampu menjelaskan Variabel Keputusan Pembelian (Y) sebesar 0,282 atau $28,2 \%$, sedangkan sisanya sebesar $71,8 \%$ dijelaskan oleh faktor lain yang tidak diteliti. Dikarenakan nilai koefisien determinasi yang dinilai rendah yaitu sebesar 28,2\%, maka dalam hal ini peneliti memberikan rekomendasi kepada peneliti yang lain untuk dapan melakukan penelitian serupa guna menyempurnakan penelitian ini dengan variabel lainnya diluar variabel yang sedang peneliti gunakan saat ini.

\section{Uji Hipotesis}

a. Uji t (t-test)

Uji t digunakan untuk menguji apakah terdapat pengaruh signifikasn antara Variabel Promosi $\left(\mathrm{X}_{1}\right)$, Kepercayaan Konsumen $\left(\mathrm{X}_{2}\right)$, terhadap Variabel Terikat yaitu Keputusan Pembelian (Y). Untuk menentukan apakah hipotesis yang diajukan signifikan atau tidak, maka perlu dilihat dari estimasi t hitung yang ditunjukan oleh tabel berikut ini :

Tabel III.9. Hasil Uji Hipotesis (Uji t)

\begin{tabular}{|c|c|c|c|c|c|}
\hline & & coefficie & & & \\
\hline \multirow[b]{2}{*}{ Model } & \multicolumn{2}{|c|}{$\begin{array}{l}\text { Understandardized } \\
\text { Coeffcients }\end{array}$} & $\begin{array}{l}\text { Standardized } \\
\text { Coeffcients }\end{array}$ & \multirow[t]{2}{*}{$\mathrm{t}$} & \multirow[t]{2}{*}{ Sig } \\
\hline & B & Std.Error & Beta & & \\
\hline 2. (constant) & 1.005 & .410 & & 2.573 & .012 \\
\hline Promosi & .373 & ,096 & .339 & 3.869 & .000 \\
\hline $\begin{array}{c}\text { Kepercayaan } \\
\text { Nasabah }\end{array}$ & .320 & .080 & .349 & 3.982 & .000 \\
\hline
\end{tabular}

Berdasarkan tabel III.9 dapat diketahui bahwa nilai $t_{\text {hitung }}$ untuk variabel Promosi $\left(\mathrm{X}_{1}\right)$ adalah sebesar 3,869, Variabel Kepercayaan Nasabah $\left(\mathrm{X}_{2}\right)$ adalah sebesar 3,982 jika dibandingkan dengan $t_{\text {tabel }}=1,98397$. Hasil setimasi tersebut menyatakan bahwa nilai $t$ hitung kedua variabel bebas atas variabel terikat lebih besar dari t tabel $\left(t_{\text {hitung }}>t_{\text {tabel }}\right)$, maka kreteria Ha diterima dan Ho ditolak, hal ini berarti kedua variabel bebas tersebut dapat dikatakan berpengaruh signifikan terhadap variabel terikat. Disisi lain, jika dibandingkan antara nilai koefisien Sig. dengan nilai P-value $(\alpha)$ sebesar 0,05, maka dapat diketahui 
bahwa koefisien Sig. variabel $\mathrm{X}_{1}$ sebesar 0,000, koefisien Sig. variabel $\mathrm{X}_{2}$ sebesar 0,000 , ketiga variabel bebas tersebut memiliki nilai koefisien Sig. yang masih dibawah nilai P-value $(\alpha)$, hal ini berarti $\mathrm{H}_{\mathrm{a}}$ diterima dan $\mathrm{H}_{0}$ ditolak, artinya bahwa ada hubungan secara signifikan antara Promosi $\left(\mathrm{X}_{1}\right)$, Kepercayaan Nasabah $\left(\mathrm{X}_{2}\right)$, terhadap Variabel Terikat yaitu Keputusan Penggunaan Layanan Digital (Y).

\section{b. Uji F (F-test)}

Hasil analisis data dengan menggunakan program IBM SPSS Statistics For Windows Relase 23.00 dapat disajikan dalam tabel berikut:

\section{Tabel III.10}

Hasil Estimasi uji F

\begin{tabular}{|c|c|c|c|c|c|}
\hline \multicolumn{6}{|c|}{ ANOVA $^{b}$} \\
\hline Model & $\begin{array}{l}\text { Sum of } \\
\text { Squares }\end{array}$ & $\mathrm{df}$ & $\begin{array}{l}\text { Mean } \\
\text { Square }\end{array}$ & $\mathrm{F}$ & Sig \\
\hline $\begin{array}{l}1 \text { Regression } \\
\text { Residual } \\
\text { Total }\end{array}$ & $\begin{array}{l}6.137 \\
15.595 \\
21.732\end{array}$ & $\begin{array}{l}2 \\
97 \\
99\end{array}$ & $\begin{array}{l}3.068 \\
.161\end{array}$ & 19.085 & $.000^{\mathrm{b}}$ \\
\hline
\end{tabular}

a. Dependent Variable: Keputusan Penggunaan Layanan Digital.

b. Predictors: (constant), Kepercayaan Nasabah, Promosi

Sumber : Hasil olah data primer

Dari tabel di atas, diketahui nilai $\mathrm{F}_{\text {hitung }}$ sebesar $19,085>$ nilai $F_{\text {tabel }}$ sebesar 3,09 dan dikuatkan dengan nilai koefisien sig. $\mathrm{F}_{\text {hitung }}$ sebesar $0,000<\mathrm{P}$ value $(\alpha)$ sebesar 0,05 . Berdasarkan kriteria pengujiannya adalah jika nilai koefisien sig. $\mathrm{F}<\mathrm{P}$-value $(\alpha)$ sebesar 0,05 berarti $\mathrm{H}_{\mathrm{a}}$ diterima dan $\mathrm{H}_{\mathrm{o}}$ ditolak. Maka dapat disimpulkan bahwa bahwa ada hubungan secara signifikan antara Variabel Bebas yaitu Promosi $\left(\mathrm{X}_{1}\right)$, Kepercayaan Nasabah $\left(\mathrm{X}_{2}\right)$, terhadap Variabel Terikat yaitu Keputusan Penggunaan Layanan Digital. (Y).

\section{SIMPULAN DAN SARAN}

\subsection{Simpulan}

Berdasarkan hasil analisis pengaruh promosi terhadap keputusan penggunaan layanan digital, dimediasi oleh promosi dan kepercayaan konsumen di Bank Sumselbabel Cabang Prabumulih, maka disimpulkan ;

1). Pengaruh variabel Promosi terhadap Kepercayaan Konsumen.

Hasil analisis data menunjukkan bahwa variabel Promosi berpengaruh terhadap variabel Kepercayaan Konsumen. Hasil analisis data memperoleh nilai $t$-value sebesar 27,182 dengan nilai t-tabel sebesar 1,965973 hal ini berarti variabel Promosi berpengaruh positif dan signifikan terhadap variabel Kepercayaan Konsumen.

2). Pengaruh variabel Kepercayaan Konsumen terhadap Keputusan Penggunaan.

Hasil analisis data menunjukkan bahwa variabel Kepercayaan Konsumen berpengaruh terhadap variabel Keputusan Penggunaan. Hasil analisis data memperoleh nilai $t$-value sebesar 4,169 dengan nilai t-tabel sebesar 1,965973. Hal ini berarti variabel Kepercayaan Konsumen berpengaruh positif dan signifikan terhadap variabel Keputusan Penggunaan

3). Pengaruh variabel Kepercayaan nasabah terhadap Keputusan Penggunaan

Hasil analisis data menunjukkan bahwa variabel Pengetahuan Konsumen berpengaruh terhadap variabel Keputusan Penggunaan. Hasil analisis data memperoleh nilai $t$-value sebesar 3,561 dengan nilai t-tabel sebesar 1,965973. Hal ini berarti variabel Pengetahuan Konsumen berpengaruh positif dan signifikan terhadap variabel Keputusan Penggunaan. 
4). Pengaruh variabel Promosi terhadap Keputusan Penggunaan.

Hasil analisis data menunjukkan bahwa variabel Promosi berpengaruh terhadap variabel Keputusan Penggunaan. Hasil analisis data memperoleh nilai $t$-value sebesar 3,342 dengan nilai $t$-tabel sebesar 1,965973. Hal ini berarti variabel Promosi berpengaruh positif dan signifikan terhadap variabel Keputusan Penggunaan.

\subsection{Saran}

1). Bank Sumselbabel Cabang Prabumulih perlu meningkatkan rasa percaya nasabah terhadap produk-produk perbankan yang ditawarkan.

2). Promosi terhadap produk-produk yang ditawarkan terus dilakukan, serta promosi bahasanya lebih komunikatif dan mudah dipahami masyarakat ( yang belum dan sudah menjadi nasabah).

3). Perubahan Performance dalam manajemen pelayanan perlu disikapi secara objektif demi kemajuan Bank Sumselbabel Cabang Prabumulih.

\section{DAFTAR PUSTAKA}

Alfansi,lizar (2012:26). Pemasaran Jasa Finansial. Jakarta: Salemba Empat, 2016.

Alma,Buchari (2016:338). Manajemen Pemasaran dan Pemasaran Jasa. Penerbit Alfabeta, Bandung.

Alma Buchari, (2010: 140). Manajemen Pemasaran dan Pemasaran Jasa. Penerbit Alfabeta, Bandung.

Andini, Suharyono dan Sunarti, 2014. Pengaruh Viral Marketing Terhadap Kepercayaan Pelanggan Dan Keputusan Pembelian (Studi Pada Mahasiswa Fakultas Ilmu Administrasi Univesitas Brawijaya Angkatan 2013 yang melakukan Pembelian Online Melalui Media
Sosial Instagram). Jurnal Administrasi Bisnis Vol.11, Nomor 1, hal 1-6.

Cant, M., Strydom,J., Jooste, C., \& Plessis, P. D. (2006). Marketing Management. (5th ed.). South Africa: Juta \& Company.

Christina Whidya Utami (2010). Manajemen Ritel (edisi 2). Jakarta: Salemba Empat.

Citra Sugianto Putri, 2016, Pengaruh Media Sosial Terhadap Keputusan Pembelian Konsumen Cherie Melalui Minat Beli. JURNAL MANAJEMEN DAN START-UP Bisnis Vol 1 NO. 05 Des 2016 Hal 594-603.

Dharmmesta, Basu Swastha dan Handoko, T. Hani (2016:25). Manajemen Pemasaran Analisis Perilaku Konsumen. Penerbit BPFEYogyakarta, 2016.

EkoYuliawan, 2011. Pengaruh Pengetahuan Konsumen Mengenai Perbankan Syariah Terhadap Keputusan Menjadi Nasabah Pada PT. Bank Syariah Cabang Bandung, Jurnal Wira Ekonomi MIkroskil Volume 1, Nomor 01, April 2011.

Essinger, J., \& Wylie, H. (2003). Customer strategy: Devising successful strategies in food and drink. Reuters Business Insight.

Grewal, Dhruv, \& Michael, L.(2010). Marketing (2nd ed.). New York: McGrawHill.

Ghozali, I. 2005. Aplikasi Analisis Multivariate Dengan Program SPSS. Badan Penerbit Universitas Diponegoro. Semarang. 
Griffin, 2005; 31 Manajemen edisi 7 jilid 1. Penerbit Erlangga Ciracas, Jakarta.

Ginting, Paham dan Sembiring, Beby KF (2010) Dosen Magister Ilmu Manajemen SPs USU.

Harjanto, R. (2009). Prinsip-prinsip periklanan. Jakarta: PT Gramedia.

Jasfar, F. 2009. Manajemen Jasa Pendekatan Terpadu. Ghalia Indonesia Jakarta.

Kotler dan Amstrong (2012:62). Prisnsipprinsip Pemasaran. Edisi 13.Jilid 1. Jakarta: Erlangga.

Kotler, P. \& Keller, K. L. (2012:150). Marketing management (14th ed.). United States of America: Pearson.

Lupiyoadi, R. (2013). Manajemen pemasaran jasa berbasis kompetensi. (edisi ketiga). Jakarta: Salemba Empat.

Madura, Jeff. (2011: p.449). Pengantar Bisnis .Penerbit Salemba Emapt edisi 4 buku 1 dan 2 .Jakarta.

Morissan, (2010). Periklanan: Komunikasi Pemasaran Terpadu. Bogor: Prenada.

Nazir, Moh. (2009) Metode Penelitian. Jakarta: Ghalia Indonesia.

Novita Ekasari, 2014. Pengaruh Promosi Berbasis Sosial Media Terhadap Keputusan Pembelian Produk Jasa Pembiayaan Kendaraan Pada PT.BFI Finance Jambi. Jurnal Penelitian Universitas Jambi Seri Humaniora Vol.16 Nomor 2, JuliDes 2014 hal,81-102 ISSN:08528349.
Prasetya dan Adi Nurmahdi. Pengaruh Kegiatan Pemasaran Digital Dan Perilaku Online Konsumen Pada Peningkatan Kesadaran Konsumen Dan Dampaknya Terhadap Keputusan Pembelian Via Website (Studi Kasus Pada E-Commerce Website PT.CAMPINA ICE CREAM INDUSTRY), hal 1-18.

Rangkuti, F. (2006). Riset Pemasaran. (5th ed.). Jakarta: Gramedia Pustaka Utama.

Saebani, Beni Ahmad (2015:239). Perilaku Konsumen Teori dan Praktik. Penerbit: Pustaka Setia, Bandung.

Siagian, S. P. (2007). Manajemen Sumberdaya Manusia. (14th ed.). Jakarta: Penerbit Bumi Aksara.

Sugiyono. (2010). Metode Penelitian Kuantitatif Kualitatif dan $R \& D$. Bandung: Alfabeta.

Sumarwan, ujang .Perilaku Konsumen Teori dan Penerapannya dalam Pemasaran. Penerbit Ghalia Indonesia .Cet.Kedua, Februari 2014. Jl. Rancamaya Km. 1 No. 47, Warung Nangka, Ciawi - Bogor 16720.

Sunyoto, Danang (2014: 6). Praktik Riset Perilaku Konsumen. Penerbit: PT.BUKU SERU, Jakarta.

Suyanto, Asep Herman. 2007. Web Design Theory and Practices.Yogyakarta: Andi.

Swastha, B. Dharmmesta dan Handoko, T hani (2016:10). Manajemen Pemasaran, Analiiss Konsumen. Edisi Pertama di cetak BPFEYogyakarta cetakan ketujuh agustus 2016. 
Tjiptono, F. 2014. Pemasaran Jasa. Penerbit Andi. Yogyakarta (Wyckof dalam Lovelock yang dikutip oleh Fandy Tjiptono, 2012) Konsep Kualitas Pelayanan Publik.

Umar, husein (2010), Riset Pemasaran Dan Perilaku Konsumen. Penerbit PT.Gramedia Bulding, Jakarta.
Yazid. (2003). Pemasaran Jasa, Edisi Kedua, Fakultas Ekonomi UII, Yogyakarta.

Zeithaml, V.A., Bitner, M.J. \& Gremler, D.D. (2006). Service marketing. $4^{\text {th }}$ edition. New York: The MC Graw-Hill Companies, Inc. 